\title{
The Students' Responses towards the Use of Procedure Genre to Make Workshop Manuals
}

\author{
Sri Hastuti \\ Department of English, Politeknik Negeri Bandung \\ Bandung, Indonesia \\ E-mail:sri.hastuti@polban.ac.id
}

\begin{abstract}
This study examined the students responses towards the use of procedure genre to make workshop manuals which was indicated by the result scores after being taught using procedure genre. Specifically, this study is aimed to know whether their response is positive or negative which is indicated by their scores. To do the study one class of 26 students of Civil Engineering Department of the Bandung State Polytechnic has been used as sample. The design of the research ist-test design, while the instruments for collecting the data are composition tests. Paired t-test was used to analyse the data to answer the research questions. The result of analysis using t-test is that the students' responses towards the use of procedure genre to make workshop manuals are positive.The result of the test shows significant improvement of students' competence after being taught. The result of the analysis answers the research questions investigated in this study. It is expected that this study will give significant contribution to the teaching of writing text in the Polytechnic
\end{abstract}

Keywords: procedure genre, workshop manuals

\section{INTRODUCTION}

Nowadays English is one of the needs of university level students to pursue their carreer in the future. In this globalized era they have to be active in using English. They should be capable of communicating any expertise they have in a unified English text either in written or spoken form.

For students majoring in engineering, the ability to use English actively is also a must for them. They should be able not only to get information on their field but also to convey their knowledge and skill ofengineeringin Englisheither in written or spoken form.

As for the written form, ttransferring the knowledge and skill on a complete piece of text is a necessity of engineering students. Their informative ideas should be conveyed systematically, thus they will be easy to understand. Every engineering 
student should be able to produce a text in appropriate schematic structure, registers and grammar.

There are a number of text types that they should be able to make, one of them is to compose a text which is used in a workshop. The text is called a simple operating manual used in a workshop which follows procedure text type. In this study, procedure text type of Genre Based Approach has been used with few additions.

Engineering students, in this case civil engineering students, have to do practical works in a workshop. Given this fact, it will be worthwhile to make a suitable text to describe the activity which will help students to be able to describe it in English and will be beneficial to be used by students of the following years. In helping the students, the researcher applied procedure genre to make operating manuals used for describing their activities. The researcher examined whether or not the application was responded positively by the students. Thus, the research questions are as follows:

1. is the students'response positive which is indicated with good scores after being taught using procedure genre ? or

2. can procedure genre be effective to help students make a text of operating manual used in a workshop (worksop manuals)?

\section{PROCEDURE GENRE}

The word genre is very common to hear in a number of fields, like music, film, etc. In language, genre is considered as a type of text. There is very wellkown approach in language which is called Genre Based Approach comprising a number of genres. One of them is procedure genre.

Procedure genre is one of genres widely used in the field of technology and science. It iss applied for making technical and science texts. Like other genres, procedure genre has social purpose, schematic structure and lexico-grammatical features. This genre is used for showing how something is done (Feeze and Joice, 1998:96). In line with this, Gerot and Wignell (1994:23) say that text of procedure genre tells the reader how to do particular job. 
In regard to this, Martin (1985:6) suggests that procedures are about how things are done. He then divides this into two types, they are Instructions and Directions. The first consists of a sequence of imperative clauses (as in recipe), and the second uses declarative clauses in the present tense with a generalized Actor realized by you. In addition to these Rose (1997:61-62) proposes a conditional procedure. This kind of procedure is used when operators take actions which are based on a condition/ a number of conditions. For example, If the precipitator by pass gas valve is open: Pressure range is $\mathrm{OK}$, go to step 5.3.7.

Procedure genre is one of genres used in scientific writing (Macken-Horarik, 2002:18). Which has these elements;social purpose, schematic structure, and lexicogrammatical features.

\section{Social purpose}

As to the social purpose Gerot and Wignell (1994: 206) state that it is used to describe how something is accomplished through a sequence of actions or steps. According to Feez and Joice (1998:95) there are two kinds of procedure genre, they are procedures and procedural recounts. The purpose of the first type is to show how to carry out an experiment or procedure, and the second type has a purpose to record procedures and results.

In regard to this, Gerot and Wignell (1994:206) say that the social function of procedure genre is to describe how something is accomplished through a sequence of actions or steps. Similarly, Callaghan and Rothery (1988:65) also suggest that a text of procedure genre is designed to describe how something is accomplished through a sequence of actions or steps.

\section{Schematic Structure}

Regarding the schematic structure Gerot and Wignell (1994: 212) mention that procedure genre typically starts with Goal, Materials ( not required for all procedural texts), and it is followed bySteps 1-n (i.e. Goal followed by a series of steps oriented to achieving the goal). Forschematic structure of this genre, Callaghan and Rothery (1988:65) mention that this genre is begun with Goal, and it is followed bySteps 1-n (i.e. Goal followed by a series of steps oriented to achieving the goal). 
In reference to this, Feez and Joice $(1998: 96,101)$ propose that each type of procedure genre has its schematic structure. For procedure type, the schematic structure is as follows:

1. aim which states the purpose and predicts the likely conclusion,

2. materials which is the list of apparatus or equipment needed and substances or objects being investigated,

3. steps which are the actions, listed in order, that are necessary to complete the experiment or procedure. Each step is written on separate line and it is written as a command.

For procedural recounts, the schematic structure is as follows:

1. aim which states the scientific purpose,

2. record of events which lists the actions that happened,

3. results which shows the results of the experiment,

4. conclusion which shows the findings of the experiment.

In applying this genre in this study the researcher asked questions to students to arouse their ideas, such as: What did you practise in a workshop? Can you show the procedure how to do it?

\section{Lexicogrammatical Features}

Schematic structure of a genre consists of stages each of which has lexicogrammatical patterns or choices. Gerot and Wignell (1994:206) suggest that procedure genre has significant lexico-grammatical features as follows:

1. focus on generalized humanagents,

2. use of simple present tense, often Imperative,

3. use mainly of temporal conjunctions (or numbering to indicate sequence),

4. use mainly of Material Processes.

Similarly, the language features proposed by Callaghan and Rothery (1988:65) are as follows: 
1. focus on generalized humanagents,

2. use of simple present tense (plus sometimes imperative,

3. use of mainly temporal conjunctive relations ,

4. use of mainly material (action) processes.

Regarding the language components of procedure type,Feez and Joice (1998:96) say as follows :

1. usually action verbs comes at the beginning of the sentence,

2. sometimes the sentence begins with time maker which tells us the order of the steps,

3. sometimes the sentence begins with a word, phrase or a clause which tells us when to do the step.

From the theories above, it can be summarized that in general procedure genre has prominent components. First, it has social purpose that is to show how to carry out an experiment or procedure. Second, the schematic structure consists of Goal, Materials ( not required for all procedural texts), and it is followed by Steps 1-n. Third, its prominent lexicogrammatical features are focus on generalized human agents, the use of simple present tense (plus sometimes imperative), the use of mainly temporal conjunctive relations, and the use of mainly material (action) processes.

The schematic structure for this study, theories from Feez and Joice (1998:96,101)andGerot and Wignell have been used with some additions and adjustments. The schematic structure used in the study is as follows :

Title

Definition

Tools

Materials

Steps

(using sequence words/temporal conjunctive adverbs) 
As for the Lexicogrammatical Features, imperative and present tense have been used in this study. While relating to registers, civil engineering terms have been used as the students used as sample are civil engineering students.

\section{METHODOLOGY}

\section{General Design}

The research was an action research which was carried out in the classroom where the researcher taught. The design followed t-test design 1 or pre-and post-treatment design(Coolidge, F.L., 2002: 156)consisting of pretest, treatment and post test. It also followed the design of the research of Hatch and Lazaraton (1991:20), that is Pre TestPostTest Design. The formula is T1 X T2. T1 is Pre Test, X is Treatment, and T2 is Post Test. The data were 52 pieces of compositions of the students collected from Pre test and Post Test, whereas the Treatment was executed by teaching the students.

\section{Data Collection}

\section{Setting and Participants}

The research was carried out, in November 2018 at Civil Construction Study Program, Civil Engineering Department of Bandung State Polytechnic, in Bandung, West Java. The students of this study program have a practical lesson in a workshop which contains anumber of activities, such as how to make a wall, how to make bowplank, wood works, etc.

The population of this research consists of the second year students of Engineering Department of a State Polytechnic in Bandung covering 14 classes and each class contains 30 students on average. As to the sample, this study used cluster sampling in that participants were not chosen randomly as individuals but they were chosen as a group and used as a sample to represent the population.

The sample of the study was one class consisting of 26 students of Class II KS-B of the third semester of Civil Construction Study Program of Civil Engineering Department. The class was regular class which was not designed specifically for this research. The class was taken as it was with the hope that the research would run naturally and the natural setting and condition would reflect the students' real ability. 
Instruments used in the research were Pre Test and Post Test. The validity and reliability of the tests have been tested following the theories from Sugiyono (2006), Hatch and Lazaraton (1991) which comprise Validity of content, Validity of construction, Validity prediction and reliability.

\section{Data Collection Procedure, Experiment, and Analysis}

The data collection procedure was carried out by conducting an experiment, the result of which was used for answering the research question. The experiment produced 52 pieces of texts comprising 26 texts of pre test, 7 texts of joint construction activity (group work), 7 texts of joint construction activity (group work), 26 texts of post test.

The experiment consisted ofpre-test, teaching-learning process, and post-test. Firstly the researcher who acted as the teacher gave pre-test 1 to know the starting writing competence of the students. The text produced were 26 texts which were marked and given scores. The texts were then analyzed for identifying the area in which students need improvement or the kinds of assistance students still needed (Emila, 2005:115, Macken-Horarik, 2002:19) and this would also give insight about the teaching program to be run.

Secondly, in the following week the teacher taught the students to make the text. This was followed by asking the students to make a text in groups. The texts produced were 7 texts. In this stage, they were free to work together, to use any resource from the internet or other sources. Meanwhile the teacher was there to assist and answer questions from the students. Their texts then were submitted. In addition to those texts, they had a homework of making text completed with pictures to be submitted via email.The texts produced for this homework were also 7 texts.

Thirdly, in the week after the teacher gave post test. In this occasion, the students were not allowed to use dictionary, resources, etc. They were not allowed to discuss with their friends either.The texts produced were 26 texts which were marked and given scores.

For analyzing the result, the scores of pre-test 1 and those of post-test were analyzed using Design 1 of dependent t-test (Coolidge, 2000:156). This design is called pre and post-treatment design in that the 'before' scores are compared with the 'after' scores. 


\section{FINDINGS, DISCUSSION AND INTERPRETATION}

This section reveals the data analysis used for answering the research question concerning the students' response or the effect of implementing procedure genre to make a text of operating manual for workshop practices.

\section{Findings}

The effectiveness was analyzed to answer the research question concerning the students' respond or the effect of implementing proceduregenre on student's competence to writetext of operating manual in a workshop. Table 1 and Figure 1 below show the result scores of Pre-testand those of Post-test.

Table 1 The scores of Pre-testand those of Post-test.

\begin{tabular}{|c|c|c|}
\hline Subject & $\begin{array}{l}\text { Score of } \\
\text { Pre-test }\end{array}$ & $\begin{array}{l}\text { Score of } \\
\text { Post-test }\end{array}$ \\
\hline 1 & 68 & 95 \\
\hline 2 & 75 & 97 \\
\hline 3 & 60 & 95 \\
\hline 4 & 65 & 95 \\
\hline 5 & 69 & 99 \\
\hline 6 & 68 & 99 \\
\hline 7 & 69 & 95 \\
\hline 8 & 69 & 88 \\
\hline 9 & 60 & 96 \\
\hline 10 & 78 & 100 \\
\hline 11 & 70 & 94 \\
\hline 12 & 70 & 98 \\
\hline 13 & 69 & 90 \\
\hline 14 & 60 & 100 \\
\hline
\end{tabular}




\begin{tabular}{|c|c|c|}
\hline 15 & 58 & 100 \\
\hline 16 & 63 & 93 \\
\hline 17 & 15 & 97 \\
\hline 18 & 69 & 100 \\
\hline 19 & 65 & 87 \\
\hline 20 & 69 & 93 \\
\hline 21 & 70 & 96 \\
\hline 22 & 45 & 96 \\
\hline 23 & 69 & 97 \\
\hline 24 & 70 & 99 \\
\hline 25 & 69 & 94 \\
\hline 26 & 70 & 95 \\
\hline Average & 64.69 & 95.69 \\
\hline $\begin{array}{c}\text { Deviation } \\
\text { Standard }\end{array}$ & 11.94 & 3.51 \\
\hline
\end{tabular}

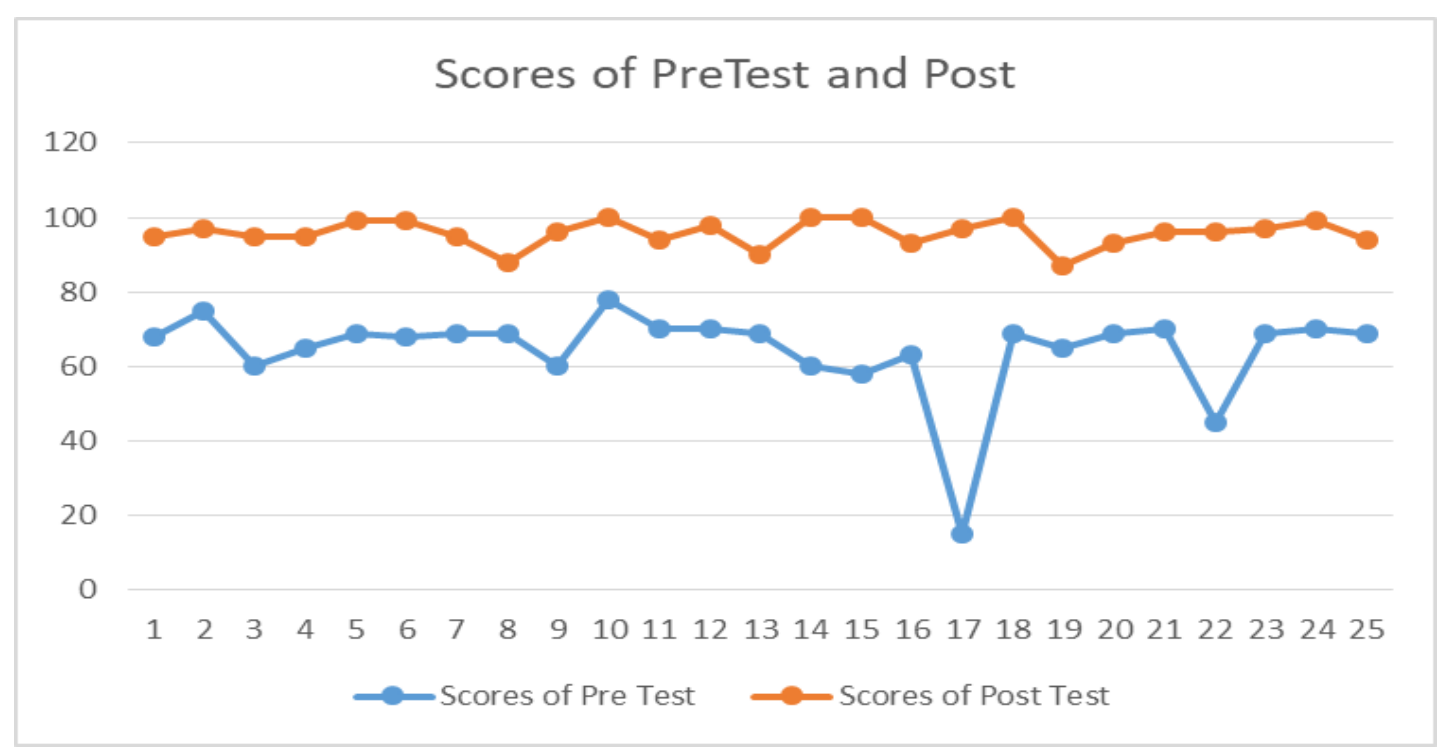

Figure 1 Score of Pre Test and Post Test 
To know the more accurate performance, statistical analysis using dependent ttesthas been conducted. The purpose of usingdependent t-test is to examine whether or not there are significant differences between twomeans. The objective of this analysis is to know the performance of the students before treatment (PreTest 1score, $\mathrm{X}_{1}$ ) and after treatment (PostTest score, $\mathrm{X}_{2}$ ). To find out the result ofstudents'competence improvement, statistical hypothesis was formulated as follows:

Ho : There are no differences between scores before and after treatment

Ho : $\mu 1=\mu 2$

$\mathrm{H}_{1}$ : There are differences between scores before and after treatment

$\mathrm{H}_{1}: \mu 1 \neq \mu 2$

To test the hypotheses, the analysis steps from Coolidge (2000:160-164) were adopted. The average score of pretest was only 64,692 and after the treatment it increased to 95,692 .

Having calculated the data $t$ calculated test has been found, that is -5.047 , while $t-$ table is \pm 2.060 for $\alpha=5 \%$.

Therefore Ho is rejected and H1 is accepted. It means that there are differences between pre test (x1) and post test (x2).

\section{Discussion and Interpretation}

Based on those data and direct observation during the treatment, it is interpreted that the considerable progress after the treatment has been resulted from the application of procedure genre. The treatment was conducted in stages as follow.

The fist was Building Knowledge of the Field in which the teacher gave them a material and let the students collect the related resources by themselves. They liked finding a number of resources which contributed to the sufficient background knowledge about the topic.

The second, the Joint Construction Stage in the form of group work, in which the teacher gave scaffolding and explicit teaching.In this stage the teacher always gave guidance and explanation to the students' questions. Conversely the students were very active in asking questions about every feature of composing the text to the teacher. The 
teacher created democratic learning atmosphere so that the students could learn collaboratively both with the teacher and their friends comfortably. In this stage the teacher used Bahasa Indonesia too if it was necessary and to make the use of the allocated time effectively.It is interpreted that once they understood the concept of composing that kind of texts they did not need to learn it again and again. Therefore the teacher emphasized on the practice.

It is predicted that these increase of competence resulted from continuous scaffolding, explicit teaching, and their sharing activities during discussion in groups. Furthermore the teacher gave intensive guidance to the students especially to the below average students. She gave explanation on what they did not understand. She continuously monitored them during joint construction stage and intervened their activity whenever they made mistakes (Feez, 2002:51-52). She corrected the mistakes on the spot. The explicit teaching done by the teacher was responded positively by them. This brought positive effect on their achievement.

Democratic discussions and clear explanations helped the low achievers catch up with the progress of the clever students and accelerated the progress of the clever students at the same time. The teacher always gave clear explanation or solution on every problem they faced (Feez, 2002: 52-53). Continuous corrections also contributed to the increasing performance and decreasingthe number of mistakes.

In group work, they were very active in looking for materials to increase their background knowledge. They liked this joint construction stage where they could share knowledge and do discussions with their teacher and friends. The result of sharing and discussion increased their confidence on the lesson which accelerated their competence. This is in line with the suggestion from Vigotsky (1978 cited in Johns 2002:56) that "learners could reach potential performance through interactive process".

In addition, it is assumed that the improvements above may also be due to several other factors. With regard to text type, their competence increased because this kind of text was manageable. The text organization was also simple. In other words their understanding of the schematic structure made them feel easy to compose the text.

Moreover, the text was relevant to their field of study. This made them courageous to learn it as they think that studying the text would be useful for increasing their 
English in their field of study. They made a success because they realized that studying to produce technical text in English especially relating to their major would be very useful for them, they found that there is a clear goal to achieve (Martin 1992 cited in John 2002:95).

\section{CONCLUSIONS}

The overall conclusion is that the students'respond is positive which is indicated by the increasing competence of the students in writing text of operating manuals used in workshop. Apart from statistical result, this can also be seen from the texts produced by the students. Their texts indicate that they can use the schematic structure correctly. Regarding registers, the students can apply them appropriately.Relating to lexicogrammatical features, they were able to convey their ideas systematically in the right kinds of sentences.

\section{Acknowledment}

This research has been funded by UPPM Polban under contract number 856.15/PL1.R7/LT/2018

\section{REFERENCES}

Callaghan, M. and Rothery, J. (1988). Teaching Factual Writing: A Genre Based Approach. Metropolitan East Region, Melbourne: MetropolitanEastDisadvantageSchool Program.

Christie, F. (2005). Language Education in Primary Years. Sydney: UNSW Press Book.

Coolidge, F.L. (2002). Statistics: A Gentle Introduction. London: SAGE Publications.

Cope, B. and Kalantzis, M. (Eds). (1993). The Powers of Literacy: A Genre Approach to Teaching Writing. London: The Falmer Press.

Cumming, J. (1985). English for Science and Technology: Architecture and Building Construction.England: Longman 
Eggins, S. (1994). An Introduction to Systemic Functional Linguistic. New York: Continum.

Emilia, E. (2005). A Critical Genre-Based Approach to Teaching Academic Writing in a Tertiary EFL Context in Indonesia, 1-2. Unpublished doctoral dissertation, Faculty of Education, The University of Melbourne.

Emilia, E. (2006). Pengajaran Keterampilan Berpikir Kritis. Paper presented at theForum Ilmiah II: Pemikiran- pemikiran Inovatif dalam Kajian Bahasa, Sastra, Seni, dan Pembelajarannya, Bandung.

Feez, S. (2002). "Heritage and Innovation in Second Language Education”. In Johns, A.M. 2002. (Ed.) Genre in the Classroom.(pp.43-69). London: Lawrence Erlbaum Associates.

Feez, S. and Joyce, H. (1998).Writing Skills:Narrative and Non-Fiction Text Types, Australia: Phoenix Education.

Flowerdew, J. (2002). "Genre in the Classroom: a Linguistic Approach". In Johns, A.M. 2002. (Ed.) Genre in the Classroom (pp.91-102). London: Lawrence Erlbaum Associates.

Gerot, L. and Wignel, P. (1994). Making sense of functional grammar. Cammeray NSW: Gerd Stabler.

Halliday, M.A.K., and Hasan, R.(1985). Language, context, and text: Aspects of Language in a social-semiotic perspective.Victoria: DeakinUniversity

Hatch, E. and Farhady, H.(1982) Research Design and Statistics for AppliedLinguistics. USA: Newbury House Publishers, inc.

Hatch, E. and Lazaraton, A. (1991). The Research Manual: Design and Statistics for Applied Linguistics. New Yor : Newbury House Publishers.

Johns, A. M (ed.). (2002). Genre in the Classroom. London: Lawrence Erlbaum Associates.

Macken-Horarik, M. (2002). "Something to shoot for: A Systemic Functional Approach to Teaching Genre in Secondary School Science”. In Johns, A.M.2002 (Ed.) Genre in the Classroom (pp.13-42). London: Lawrence Erlbaum Associates. 
Martin, J.R. (1985). Factual Writing: exploring and challenging social reality. Victoria : DeakinUniversity

Martin, J.R. and Rotehry, J. (1993). "Grammar: Making Meaning in Writing”. In Cope, B. and Kalantzis, M. 1993 (Eds). The Powers of Literacy: A Genre Approach to Teaching Writing (pp.137-178). London: The Falmer Press.

Richard,C.J., Platt, J., and Platt, H. (1992). Dictionary of Language Teaching Applied Linguistics.UK: Longman.

Rose, D. (1997). "Science, technology and technical literacies". In Christie, F. and Martin, J.R. 1997 (Eds.) Genre and Institutions. London : Continuum.

Sugiyono (2007). Memahami Penelitian Kualitatif. Bandung:Alfabeta 